\title{
IMPLEMENTASI PENGEMBANGAN KURIKULUM
}

\author{
Rosmiaty Azis \\ Fakultas Tarbiyah dan Keguruan UIN Alauddin Makassar \\ Email: andirosmiatyazs@gmail.com
}

\begin{abstract}
Implementation curriculum is a very decisive component in an educational system, therefore the curriculum is a tool to achieve the education system, therefore the curriculum is a tool to achieve the goals of education and as well as a guide in the implementation of teaching on all types and levels of education, the curriculum is part of a learning process allows learners to know (learning to know), learn to do something (learning to do) to learn to learn and learn to live together (learning to live together). Thus the learning outcomes realize students who are able to membelajarkan on himself, get some knowledge, learners are able to develop in a wider form and can be applied in everyday life.
\end{abstract}

Keywords: Implementation, Development, and Curriculum

\section{PENDAHULUAN}

urikulum sebagai rancangan pendidikan mempunyai kedudukan yang sangat
strategis dalam seluruh aspek kegiatan pendidikan. Mengingat pentingnya
peranan kurikulum dalam pendidikan, maka dalam penyusunannya harus mengacu pada landasan yang kokoh dan kuat. Landasan pengembangan kurikulum tidak hanya diperlukan bagi para penyusun kurikulum (makro) atau kurikulum tertulis yang sering disebut juga sebagai kurikulum ideal, akan tetapi juga harus dipahami dan dijadikan dasar pertimbangan oleh para pelaksana kurikulum (mikro) yaitu para pengawas pendidikan dan para guru serta pihak-pihak lainnya yang terkait dengan tugas-tugas pengelolaan pendidikan, sebagai bahan untuk dijadikan instrumen dalam melakukan pembinaan terhadap implementasi kurikulum di setiap jenis dan jenjang pendidikan. Dengan posisinya yang penting tersebut, maka penyusunan dan pengembangan kurikulum tidak bisa dilakukan secara sembarangan, akan tetapi harus didasarkan pada berbagai pertimbangan, atau landasan agar dapat dijadikan dasar pijakan dalam menyelenggarakan proses pendidikan, sehingga dapat memfasilitasi tercapainya tujuan pendidikan dan pembelajaran secara lebih efisien dan efektif. ${ }^{1}$

Landasan pengembangan kurikulum memiliki peranan yang sangat penting, sehingga apabila kurikulum diibaratkan sebagai sebuah bangunan gedung yang tidak menggunakan landasan atau fundasi yang kuat, maka ketika diterpa angin atau terjadi goncangan, bangunan gedung tersebut akan mudah rubuh dan rusak. Demikian pula

${ }^{1}$ Ahmad Tafsir, Ilmu Pendidikan dalam Perspektif Islam, (Bandung: Remaja Rosdakarya, 2004), 
halnya dengan kurikulum, apabila tidak memiliki dasar pijakan yang kuat, maka kurikulum tersebut akan mudah terombang-ambing dan yang akan dipertaruhkan adalah manusia (peserta didik) yang dihasilkan oleh pendidikan itu sendiri.

Istilah kurikulum sering dimaknai plan for learning (rencana pendidikan). Sebagai rencana pendidikan kurikulum memberikan pedoman dan pegangan tentang jenis, lingkup, urutan isi dan proses pendidikan. ${ }^{2}$ Secara historis, istilah kurikulum pertama kalinya diketahui dalam kamus Webster tahun 1856. Pada mulanya istilah kurikulum digunakan dalam dunia olah raga, yakni suatu alat yang membawa orang dari start sampai ke finish. Kemudian pada tahun 1955, istilah kurikulum dipakai dalam bidang pendidikan, dengan arti sejumlah mata pelajaran di suatu perguruan. ${ }^{3}$

Secara etimologi kata kurikulum diambil dari bahasa Yunani, Curere berarti jarak yang harus ditempuh oleh pelari dari mulai start sampai finish. Pengertian inilah yang kemudian diterapkan dalam bidang pendidikan. Dalam bahasa arab, kurikulum sering disebut dengan istilah al-manhaj, berarti jalan yang terang yang dilalui manusia dalam bidang kehidupannya. Maka dari pengertian tersebut, kurikulum jika dikaitkan dengan pendidikan, menurut Muhaimin, maka berarti jalan terang yang dilalui oleh pendidik atau guru dengan peserta didik untuk mengembangkan pengetahuan, keterampilan dan sikap serta nilai-nilai. ${ }^{4}$

Penddikan Agama Islam merupakan mata pelajaran yang wajib diajarkan setiap jenjang pendidikan, yaitu mulai pendidikan dasar sampai keperguruan tinggi, hal ini sesuai dengan UU RI No. 20 Tahun 2003 pada bab X pasal 37 ayat 1 dan 2 yaitu isi kurikulum pendidikan dasar dan menengah wajib memuat: pendidikan agama, pendidikan kewarganegaraan, bahasa, matematika, ilmu pengetahuan alam, ilmu pengetahuan sosial, seni dan budaya, pendidikan jasmani dan olahraga, keterampilan/kejuruan; danmuatan lokal. ${ }^{5}$ Pendidikan agama mengemban amanat sekaligus, yaitu bidang agama dan bidang pendidikan, di bidang pendidikan, pendidikan agama di sekolah merupakan bagian integral dari program pendidikan dan pengajaran pada setiap jenjang dan jenis pendidikan untuk mencapai tujuan nasional.

\section{PEMBAHASAN}

\section{A. Proses Implementasi Kurikulum dalam KBM}

Proses Pembelajaran Pendidikan Agama Islam (PAI)

Pembelajaran Pendidikan Agama Islam (PAI) merupakan bentuk nyata

${ }^{2}$ Nana Syaodih Sukmadinata, Pengembangan Kurikulum, Teori dan Praktek, (Bandung: Remaja Rosdakarya, 2004), h. 4

${ }^{3}$ Ahmad Tafsir, Ilmu Pendidikan dalam Perspektif Islam, h. 53

${ }^{4}$ Muhaimin, Pengembangan Kurikulum Pendidikan Agama Islam, di Sekolah, Madrasah dan Perguruan Tinggi, (Jakarta: Raja Grafindo Persada, 2005), h. 1

${ }^{5}$ Undang-Undang Republik Indonesia No. 20 Tahun 2003, Tentang Sistem Pendidikan Nasional, PT. Mediawiyata, Semarang, 1990, h. 15. 
implementasi kurikulum Pendidikan Agama Islam (PAI) dalam kelas yang melibatkan unsur-unsur personal (kepala sekolah dan guru) peserta didik, sumber belajar, serta sarana dan prasarana pendukung lainnya. Keberhasilan dalam pembelajaran menjadi indikator keberhasilan sutau implementasi. Para ahli mengemukakan tentang konsep pembelajaran, diantaranya Sujana mengatakan bahwa pembelajaran atau belajar dan mengajar merupakan dua konsep yang tidak bisa dipisahkan satu sama lain. Belajar merujuk pada apakah yang harus dilakukan seseorang sebagai subjek (sasaran didik) sedangkan mengajar merujuk pada apa yang harus dilakukan oleh guru sebagai pengajar. ${ }^{6}$

Menurut Nana Syaidih bahwa pembelajaran mengandung berbagai komponen, yaitu komponen peserta didik, guru, sarana dan kurikulum, kurikulum sebagai komponen pembelajaran terdiri tujuan, materi, proses, dan penilaian. Dengan pedoman kurikulum guru memberikan perlakuan profesional sehingga tercipta interaksi dalam pembelajaran, perlakuan guru untuk mempertautkan kegiatan mengajar dengan kegiatan belajar mengacu pada kurikulum yang dikenal sebagai kegiatan belajar mengajar . 7

Pendapat lain dikemukakan oleh Ahmad Sanusi bahwa mengajar adalah salah satu bentuk usaha pendidikan, mengajar dalam arti luas diartikan proses pendidikan atau pembelajaran peserta didik yang diasumsikan mempunyai fungsi seperti membantu, menumbuhkan dan mestranformasikan nilai-nilai positif sambil memberdayakan serta mengembangkan potensi-potensi kepribadian peserta didik. ${ }^{8}$

Para ahli lain sebagaimana diungkapklan oleh Tafsir bahwa makna pembelajaran atau kegiatan belajar mengajar PAI dalam kaitan menanamkan keimanan dan ketaqwaan bukan saja dalam bentuk mengajar, melainkan harus diikuti oleh bentuk lain, seperti membimbing, melatih, serta memberikan contoh yang baik. ${ }^{9}$

Soedijarto mengemukakan bahwa suatu proses pembelajaran memungkinkan peserta didik untuk mengetahui (learning to know), belajar untuk melakukan sesuatu (learning to do) belajar untuk mandiri (learning to be) dan belajar untuk hidup bersama (learning to live together). Dengan demikian hasil pembelajaran mewujudkan peserta didik yang mampu membelajarkan pada dirinya, mendapatkan sejumlah pengetahuan, peserta didik mampu mengembangkan dalam bentuk lebih luas serta dapat diterapkannya dalam kehidupan sehari-hari. ${ }^{10}$

Kaitannya dengan pembelajaran pendidikan agama Islam dalam meningkatkan ketaqwaan, maka dapat diartikan bahwa pembelajaran PAI sebagai perlakuan

\footnotetext{
${ }^{6}$ Nana Sudjana Ibrahim, Penelitian dan Penilaian Islam, Sinar Baru, Jakarta, 1995, h. 28.

${ }^{7}$ Nana Sudjana Ibrahim, Penelitian dan Penilaian Islam,h.5.

${ }^{8}$ Ahmad Sanusi, Strategi Kurikulum Menuju Iman dan Taqwa, Makalah IAIN, SGD, Bandung, h.2.

${ }^{9}$ Ahmad Tafsir, Ilmu Pendidikan Islam dalam Persepektif Islam, Remaja Rosda Karya, Bandung, 1992, h. 74.
}

${ }^{10}$ Suryo Subroto, Sistem Pengajaran dengan Modul, Bina Aksara, Bandung, 1998, hlm. 4. 
profesional guru agama terhadap peserta didiknya sehingga menghasilkan peserta didik yang mempunyai kemampuan untuk mengetahui, menghayati, dan mengembangkan pengetahuan, untuk dipedomani dan dilaksanakan dalam kehidupannya sebagai seorang muslim yang beriman dan bertaqwa dalam kehidupan pribadi dan bermasyarakat.

Kegiatan implementasi kurikulum pendidikan agama Islam dapat dievaluasi dengan melihat 4 aspek yaitu : tujuan, strategi, isi materi pelajaran dan kegiatan evaluasi. Dibawah ini merupakan hasil observasi tentang kegitan pembelajaran di kelas.

(a) Aspek tujuan

Tujuan yang ingin dicapai dalam proses belajar mengajar tidak dikemukakan sehingga guru seakan-akan berjalan tanpa arah yang benar. Oleh karena itu tujuan pembelajaran mesti dirancang sampai pada tingkat operasional artinya tujuan tersebut bersipat operasioanl, terukur dan teramati sampai tingkat keberhasilannya. Tujuan yang dirumuskan lebih berorentasi kepada pengembangan potensi yang dimiliki oleh peserta didik.

(b) Aspek materi

Uraian materi sebagai bahan ajar kurang mendapatkan pengembangan, guru cukup mengandalkan buku yang ada pada diri peserta didik, sehingga ruang lingkup pembahasannya sangat terbatas. Padahal materi tersebut bisa dikembangkan dengan melihat berbagai dimensi lain serta literature yang ada diperpustakaan. Oleh karena aspek materi merupakan salah satu bagian terpenting dalam pengembangan proses pembelajaran maka, guru dapat merumuskan secara sistematis sesuai dengan tingkat kemampuan peserta didik. Dalam pengembangan aspek materi pembelajaran dapat dilakukan dengan pendekatan "Concept Map" (Peta konsep).

(c) Aspek strategi

Dalam proses belajar mengajar mereka mampu menggunakan salah satu strategi aktif, sehingga peserta didik dapat belajar dengan penuh semangat dan antusias untuk mengikuti pembelajaran di kelas. Secara umum penggunaan strategi aktif sudah terlaksana walaupun masih ada kekurangannya. Penggunaan strategi aktif dalam proses pembelajaran merupakan suatu kaharusan dalam kegiatan belajar mengajar. Oleh karena itu Strategi merupakan komponen yang menentukan terhadap keberhasilan kegiatan belajar mengajar disamping tujuan, materi dan evaluasi. Strategi yang digunakan adalah betul-betul dapat membangkitkan semangat peserta didik dalam belajar. Strategi yang dapat melayani kebutuhan peserta didik, baik secara individu maupun kelompok merupakan suatu hal yang diharapkan saat ini. Penggunaan strategi yang tepat dapat berpengaruh terhadap efektivitas kegiatan belajar mengajar.

(d) Aspek evaluasi

Aspek ini tidak terlaksana dengan sempurna. Kegiatan evaluasi hanya terbatas pada test tulisan dan lisan sedangkan aspek yang lain yaitu evaluasi bentuk non test tidak pernah dilaksanakan. Nampaknya persoalan evaluasi tidak terlalu diperhatikan, 
padahal evaluasi merupakan komponen yang tidak kalah penting dengan komponen lain dalam pelaksanaan pembelajaran. Kegiatan evaluasi ini berguna untuk melihat keberhasilan proses pembelajaran. Dengan evaluasi dapat diketahui baik dan tidaknya mutu suatu pendidikan. Kegiatan evaluasi sekaligus dapat melihat tepat atau tidaknya tujuan yang dirumuskan, materi yang diajarkan dan strategi yang digunakan.

\section{B. Faktor-faktor Pendukung Implementasi Kurikulum Pendidikan Agama Islam (PAI) dalam Kegiatan Belajar Mengajar (KBM)}

Dalam proses implementasi kurikulum PAI dalam KBM di kelas sangat dipengaruhi oleh beberapa faktor pendukung keberhasilan implementasi kurikulum. Adapun faktor-faktor pendukung implementasi kurikulum PAI sebagai berikut:

a. Faktor Guru

Guru merupakan salah satu unsur di bidang pendidikan yang berperan aktif dan menempatkan kedudukannya sebagai tenaga profesional, sesuai dengan tuntutan masyarakat yang semakin berkembang. Karena itu guru tidak semata-mata sebagai "transfer of values" pengajar, melainkan juga sebagai pembimbing yang memberikan pengarahan dan menuntun peserta didik dalam belajar.

Faktor guru cukup berperan dalam implementasi kurikulum dan berakibat langsung pada perubahan sekolah sebagai sistem sosial.

Keberhasilan pendidikan agama Islam dapat dipengaruhi oleh beberapa faktor. Collin J. Marsh (1980) dalam "Curriculum Process in The Primary School" mengemukakan bahwa ada lima unsur yang dapat dipengaruhi terhadap keberhasilan pembelajaran di sekolah, yaitu :

1) Dukungan dari kepala sekolah

2) Dukungan dari teman sejawat atau sesama guru

3) Dukungan dari peserta didik sebagai peserta didik

4) Dukungan dari orang tua atau peserta didik

Dari kelima unsur di atas, yang paling menentukan berhasil tidaknya suatu proses pembelajaran di dalam kelasm ada lah faktor guru, posisi dan peran guru. Dalam pendidikan merupakan ujung tombak dalam menentukan berhasil tidaknya suatu rancangan pembelajaran. Guru tidak hanya berperan sebagai pengajar melainkan sebagai pembimbing, pemimpin, ilmuwan, pribadim penghubung, pembaharu dan pembangun.

Ditandaskan kembali dalam buku "Basic Princples of Student Teadhing" oleh Adan dan Dicky serta alih bahasa Oemar Hamalik di sebutkan bahwa peranan guru sesungguhnya sangat luas, meliputi : 1) teacher as intructor (guru sebagai pengajar); 2) teacher as counsellor (guru sebagai pembimbing); 3) teacher as scientist (guru sebagai ilmuwan) dan 4) teacher as person (guru sebagai pribadi). 


\section{b. Faktor Peserta didik}

Peserta didik merupakan raw input yang menunjukkan pada faktor-faktor yang terdapat dalam individu serta memungkinkan seseorang dapat belajar. Adapun faktorfaktor tersebut meliputi: bakat, pengetahuan, sikap, usia, jenis kelamin dan sosial ekonomi .

\section{c. Faktor Lingkungan}

Keberhasilan proses dan hasil belajar ditentukan pula oleh sarana dan prasarana yang memadai serta didukung oleh kondisi lingkungan yang kondusif. Lingkungan dikatakan sebagai faktor penentu kedua keberhasilan proses pendidikan agama Islam, sesudah faktor pembawaan. Hal ini didasarkan atas hukum "konvergensi" yang menyatakan bahwa yang menentukan masa depan seseorang, apakah ia menjadi orang yang baik atau sebaliknya, senang gembira atau sebaliknya sangat ditentukan oleh faktor lingkungan dimana ia berada dan faktor pembawaan.

Faktor lingkungan ini meliputi lingkungan sekolah dan lingkungan keluarga (orang tua dan masyarakat). Lingkungan sekolah yang melibatkan hubungan sosial dan sekolah, yaitu hubungan kepala sekolah dan guru, guru dengan guru, guru dengan peserta didik, dan peserta didik dengan peserta didik itu sendiri, juga termasuk hubungan sekolah dengan masyarakat dalam hal ini orang tua peserta didik. Menurut Mulyani Sumantri berpendapat bahwa keterlibatan atau peran orang tua peserta didik maupun anggota masyarakat sangat diperlukan dalam penyelenggaraan sekolah, terutama dalam menghadapi masalah-masalah yang amat penting dalam meningkatkan kualitas dan kwantitas sekolah (pendidikan). Kaitannya dengan pendidikan agama bahwa orang tua dan masyarakat sangat menentukan perubahan perilaku peserta didik.

\section{KESIMPULAN}

1. Pengembangan kurikulum adalah suatu proses yang merencanakan, menghasilkan suatu alat yang lebih baik dengan didasarkan pada hasil penelitian terhadap kurikulum yang tidak berlaku, sehingga dapat memberikan kondisi kegiatan belajar mengajar yang lebih baik

2. Landasan Kurikulum dapat diartikan sebagai suatu gagasan, landasan, suatu asumsi, atau prinsip yang menjadi sandaran atau titik tolak dalam mengembangkan kurikulum.

3. Ada lima landasan pokok yang harus dijadikan dasar dalam setiap pengembangan kurikulum yaitu landasan teologis, filosofis, psikologis, sosiokultural, ilmu pengetahuan dan teknologi.

4. Proses Implementasi Kurikulum dalam KBM yaitu Proses pembelajaran kurikulum pendidikan agama Islam sebagai rencana memiliki komponen-komponen yang terdiri dari tujuan, materi pelajaran, proses atau metode, serta penilaian.

5. Faktor-faktor pendukung Implementasi Kurikulum Pendidikan Agama Islam dalam Kegiatan Belajar Mengajar 

a. Faktor Guru
b. Faktor Peserta didik
c. Faktor Lingkungan.

\section{DAFTAR PUSTAKA}

Muhaimin, Arah Baru Pengembangan Pendidikan Islam, Nuansa, Bandung, 2003.

Nana Sudjana Ibrahim, Penelitian dan Penilaian Islam, Sinar Baru, Jakarta, 1995.

Ahmad Sanusi, Strategi Kurikulum Menuju Iman dan Taqwa, Makalah IAIN, SGD, Bandung.

Ahmad Tafsir, Ilmu Pendidikan Islam dalam Persepektif Islam, Remaja Rosda Karya, Bandung, 1992.

Suryo Subroto, Sistem Pengajaran dengan Modul, Bina Aksara, Bandung, 1998.

Depdikbud, Kurikulum Pendidikan Agama Islam (PAI) SMP, Jakarta, 1987.

Depag. RI, Pendidikan Agama Islam untuk Peserta didik SMP, Dirjen Binbaga, Jakarta, 1999.

Depag. RI, Kurikulum Pendidikan Agama Islam Untuk Tingkat SMP, Dirjen Binbaga, Jakarta, 1994.

Djambari, Agama dalam Perspektif Sosial, Depdikbud, Jakarta, 1998.

Nana Syaodih Sukmadinata, Pengembangan Kurikulum, Teori dan Praktek, (Bandung: Remaja Rosdakarya, 2004)

Ahmad Tafsir, Ilmu Pendidikan dalam Perspektif Islam, (Bandung: Remaja Rosdakarya, 2004).

Endang Mulyasa, Kurikulum Tingkat Satuan Pendidikan, Suatu Panduan Praktis, (Bandung: Remaja Rosdakarya, 2006).

Murrary Print, Curriculum Design and Development, (Australia: Allen \& Unwin, 1993). 